\title{
The Site of the Maykop Culture in the Mountains of the Northwestern Caucasus
}

\author{
S. M. Ostashinskii, E. A. Cherlenok
}

For citation: Ostashinskii S. M., Cherlenok E. A. The Site of the Maykop Culture in the Mountains of the Northwestern Caucasus. Vestnik of Saint Petersburg University. History, 2021, vol. 66, issue 2, pp. 585-601. https://doi.org/10.21638/11701/spbu02.2021.216

The Meshoko rock shelter was first explored in the 1960s. Along with some other settlements in the vicinity, its materials were interpreted as evidence of the synchronism of the early Maykop and late Eneolithic cultures. Modern excavations have shown that Maykop and Eneolithic finds are concentrated in different layers, with natural deposits between them. The stratigraphic sequence of the Meshoko rock shelter consisted of six main layers. Maykop artifacts were in the third layer from above. The most interesting object discovered there is the hearth, the base and walls of which were formed by limestones. No evidence of a dwelling was found, which probably indicates the temporary nature of the settlement. The few Eneolithic materials cannot be confidently synchronized with the Maykop culture. It is more likely that they were introduced into the third layer through pits which were dug down from the Maykop level. The bulk of the collection of the third layer is associated with the Maykop culture, most likely with the middle stage of its development (Inozemtsevo-Kostromskaia). This conclusion corresponds to the radiocarbon dates of the settlement, which were about 3600-3000 BC. The Meshoko rock shelter is located at the bottom of the mountain gorge. This is unusual for Maykop sites, which, as a rule, occupy the steppe and flat areas of the foothills. Also, there are no close analogies in the paleoethnobotany and archaeozoology assemblages. The study of these ecofacts indicate that the Maykop population probably lived in a forest zone and was well adapted to the conditions of the local environment.

Keywords: the Northwestern Caucasus, the Maykop culture, Eneolithic, cultural attribution, chronology.

\section{Памятник майкопской культуры в горах Северо-Западного Кавказа}

\section{С. М. Осташинский, Е.А. Черленок}

Для цитирования: Ostashinskii S. M., Cherlenok E. A. The Site of the Maykop Culture in the Mountains of the Northwestern Caucasus // Вестник Санкт-Петербургского университета. История. 2021. T.66. Вып. 2. С. 585-601. https://doi.org/10.21638/11701/spbu02.2021.216

Sergei M. Ostashinskii - Researcher, State Hermitage Museum, 34, Dvortsovaya nab., St. Petersburg, 190000, Russian Federation; osm@mail.ru

Сергей Матвеевич Осташинский - науч. сотрудник, Государственный Эрмитаж, Российская Федерация, 190000, Санкт-Петербург, Дворцовая наб., 34; osm@mail.ru

Evgenii A. Cherlenok - PhD (History), Senior Lecturer, St. Petersburg State University, 7-9, Universitetskaya nab., St. Petersburg, 199034, Russian Federation; e.cherlenok@spbu.ru

Евгений Александрович Черленок - канд. ист. наук, ст. преп., Санкт-Петербургский государственный университет, Российская Федерация, 199034, Санкт-Петербург, Университетская наб., 7-9; e.cherlenok@spbu.ru

(C) St. Petersburg State University, 2021 
Первые раскопки навеса Мешоко состоялись в 1960-х гг. Результаты этих работ и материалы, относящиеся к некоторым другим поселениям в окрестностях, рассматривались как свидетельство синхронности майкопской и поздней энеолитической культур. В ходе современного этапа изучения памятника выяснилось, что майкопские и энеолитические находки сконцентрированы в разных слоях. Кроме того, между ними были зафиксированы отложения, сформировавшиеся в силу естественных причин. Стратиграфия навеса Мешоко в настоящее время насчитывает шесть основных слоев. К майкопской культуре можно отнести только третий сверху слой. Наиболее интересным объектом, обнаруженным здесь, является очаг, дно и стенки которого были обложены известняковыми камнями. При этом не было найдено никаких признаков жилища, что, вероятно, указывает на временный характер поселения. Важно отметить, что зафиксированные в ходе работ немногочисленные энеолитические находки не позволяют уверенно синхронизировать время существования майкопской и энеолитической культур. На наш взгляд, они попали в третий слой в результате устройства «майкопцами» многочисленных ям, что привело к перемещению части энеолитических материалов в вышележащие отложения. В своей массе коллекция третьего слоя связана с майкопской культурой, скорее всего, со средним (иноземцево-костромским) этапом ее развития. Этому выводу не противоречат данные радиоуглеродного датирования, которые указывают на период около 3600-3000 гг. до н.э. как наиболее вероятное время формирования майкопского слоя. Навес Мешоко располагается в нижней части горного ущелья. Это очень необычно для памятников майкопской культуры, которые, как правило, занимают степь и равнинные участки предгорий. Также не находит близких аналогий состав палеозоологической и палеоботанической коллекций. Их анализ свидетельствует о том, что майкопское население навеса, вероятно, жило не просто в горах, а в горной лесной зоне и при этом было хорошо адаптировано к окружающей природной среде.

Ключевые слова: Северо-Западный Кавказ, майкопская культура, энеолит, культурная атрибуция, хронология.

\section{Introduction}

The main area of the Maykop culture is the foothills and flat plains of the North Caucasus. It is here that its settlements and funerary monuments were concentrated throughout the early Bronze Age period. The data available on mountainous regions are scarcer. As a rule, only local Eneolithic settlements were found there, some of them containing scant Maykop artifacts ${ }^{1}$. One of the mountain sites with Maykop materials is the Meshoko rock shelter, which was excavated from 1963 to 1964 by Abram D. Stoliar². Unfortunately, the results of these digs were not published, although they were mentioned as an argument

1 Trifonov V.A. Osobennosti lokal'no-chronologicheskogo razvitiiia maykopskoi kul'tury // Maykopskii fenomen v drevnei istorii Kavkaza i Vostochnoi Evropy: tezisy dokladov. Leningrad, 1991. P.26-27; Rezepkin A.D. Keramicheskie kompleksy poselenii Khadzhokh, Skala, Iasenova poliana // Sud'ba uchenogo: K 100-letiiu so dnia rozhdeniia Borisa Aleksandrovicha Latynina. St. Petersburg, 2000. P. 234; Trifonov V.A. Darkveti-meshokovskaia kul'tura // Tret'ia Kubanskaia archeologicheskaia konferentsiia. Krasnodar; Anapa, 2001. P. 193; Korenevskii S. N. Poselenie eneoliticheskoi epokhi Predkavkaz'ia Iaseneva Poliana i kul'tura nakol'chatoi zhemchuzhnoi keramiki Predkavkaz’ia // Problemy istorii, filologii, kul'tury. 2008. No. 21. P. 135; Rysin M. B. Problemy khronologii i periodizatsii drevnikh kul'tur Kavkaza (radiokarbonnaia "revolutsia" i traditsionnaia arkheologicheskaia tipologiia) // Arkheologicheskie vesti. 2012. No. 18. P. 208.

2 Stoliar A. D. Otchet o rabotakh Severokavkazskoi ekspeditsii Gosudarstvennogo Ermitazha v 1963 g. // Meshoko - drevneishaia krepost' Predkavkaz'ia. Otchety Severokavkazskoi arkheologicheskoi ekspeditsii 1958-1965 gg. St. Petersburg, 2009. P. 107-108. 
about the presence of Eneolithic and Maykop ceramic fragments in the same context ${ }^{3}$. In 2011, the study of the Meshoko rock shelter was resumed. Since then, it has been explored by the Transkuban expedition of the State Hermitage museum in cooperation with St. Petersburg State University. New research shines a light on the stratigraphy of the site. In particular, it has turned out that the artifacts of the Maykop and local Eneolithic cultures belonged to different layers ${ }^{4}$.

This publication analyses some aspects related to the Maykop layer of the Meshoko rock shelter. The focus will be on the characteristics of the culture of the Maykop rock shelter located in the mountainous region in comparison with the sites of the main area of Maykop culture. The issue of mutual contacts between the Maykop and the local Eneolithic population will also be addressed.

\section{Location}

The Meshoko rock shelter is situated $1.2 \mathrm{~km}$ southeast of the village of Kamennomostsky on the left bank of the Meshoko Brook which flows into the Belaya River. Its width and height at the mouth are 35 and $3.9 \mathrm{~m}$, and its depth is $18 \mathrm{~m}$ (Fig. 1). The entrance is oriented north-east. There is no flat area in front, and a steep slope to the stream begins approximately from the drip line. The rocky bed of the Meshoko Brook is about $6 \mathrm{~m}$ below the floor level. The Meshoko Brook has high steep banks all along, but about $100 \mathrm{~m}$ west of the shelter the rocky terrain decreases, forming a convenient crossing from one bank to the other. The rock shelter is one of the largest sites of its kind in the area. Apparently, its size and convenient location near the crossing decisively contributed to its attractiveness to the ancient population.

The surroundings of the village of Kamennomostsky are a classic area of the Eneolithic culture. In addition to Meshoko rock shelter, seven Eneolithic sites were excavated there (Fig. 2). On some of them, the Eneolithic and Maykop materials were recorded together (Khadzhokh rock shelters ${ }^{5}$, Unakozovskaia cave ${ }^{6}$, Khutor Veselyi settlement ${ }^{7}$ ). On others, artifacts of the Maykop culture were not found (Meshoko settlement ${ }^{8}$, Skala settlement ${ }^{9}$, Kamennomostskaya cave ${ }^{10}$ and probably Dakhovskaya cave $\left.{ }^{11}\right)$.

${ }^{3}$ Korenevskii S.N.: 1) Drevneishie zemledel'tsy i skotovody Predkavkaz'ia. Moscow, 2004. P.12; 2) Poselenie eneoliticheskoi epokhi Predkavkaz'ia Iaseneva Poliana... P. 122.

${ }^{4}$ Ostashinskii S.M., Cherlenok E. A. Novye dannye o sootnoshenii pozdneeneoliticheskoi i Maykopskoi kul'tury v predgor'iakh Severo-Zapadnogo Kavkaza // Shestaia Mezhdunarodnaia Kubanskaia arkheologicheskaia konferentsiia: materialy konferentsii. Krasnodar, 2013. P. 321-324.

${ }^{5}$ Rezepkin A.D. Keramicheskie kompleksy... P. 223-235.

${ }^{6}$ Lovpache N. G. Etnicheskaia istoriia Zapadnoi Cherkesii (s VI tysiacheletiia do n. e. po XIX v.). Maykop, 1997. Fig. 4.

7 Formozov A.A., Chernykh E.N. Novye poseleniia Maykopskoi kul'tury v Prikuban'e // Kratkie soobshcheniia Instituta arkheologii. 1964. Iss. 101. Fig. 31: 13.

${ }^{8}$ Meshoko - drevneishaia krepost' Predkavkaz'ia; Ostashinskiy S. M.: 1) Materialy raskopok 2007 g. na poselenii Meshoko // Arkheologicheskie vesti. 2012. No. 18. P. 43-66; 2) Materialy raskopok 2008 g. na poselenii Meshoko // Kavkazologia. 2019. No. 3. P.38-61.

9 Formozov A.A. Poseleniia Adygei epokhi rannego metalla // Sbornik materialov po arkheologii Adygei. No. 3. Maykop, 1972. P. 5-10.

${ }_{10}$ Formozov A. A. Kamennomostskaia peshchera - mnogosloinaia stoianka v Prikuban'e // Paleolit i neolit SSSR. 1971. T. 6. P. 100-116.

${ }^{11}$ Formozov A. A. Arkheologicheskie issledovaniia peshchervverkhov'iakh reki Beloi v Krasnodarskom krae // Sbornik materialov po arkheologii Adygei. No. 2. Maykop, 1961. P.40-50. 


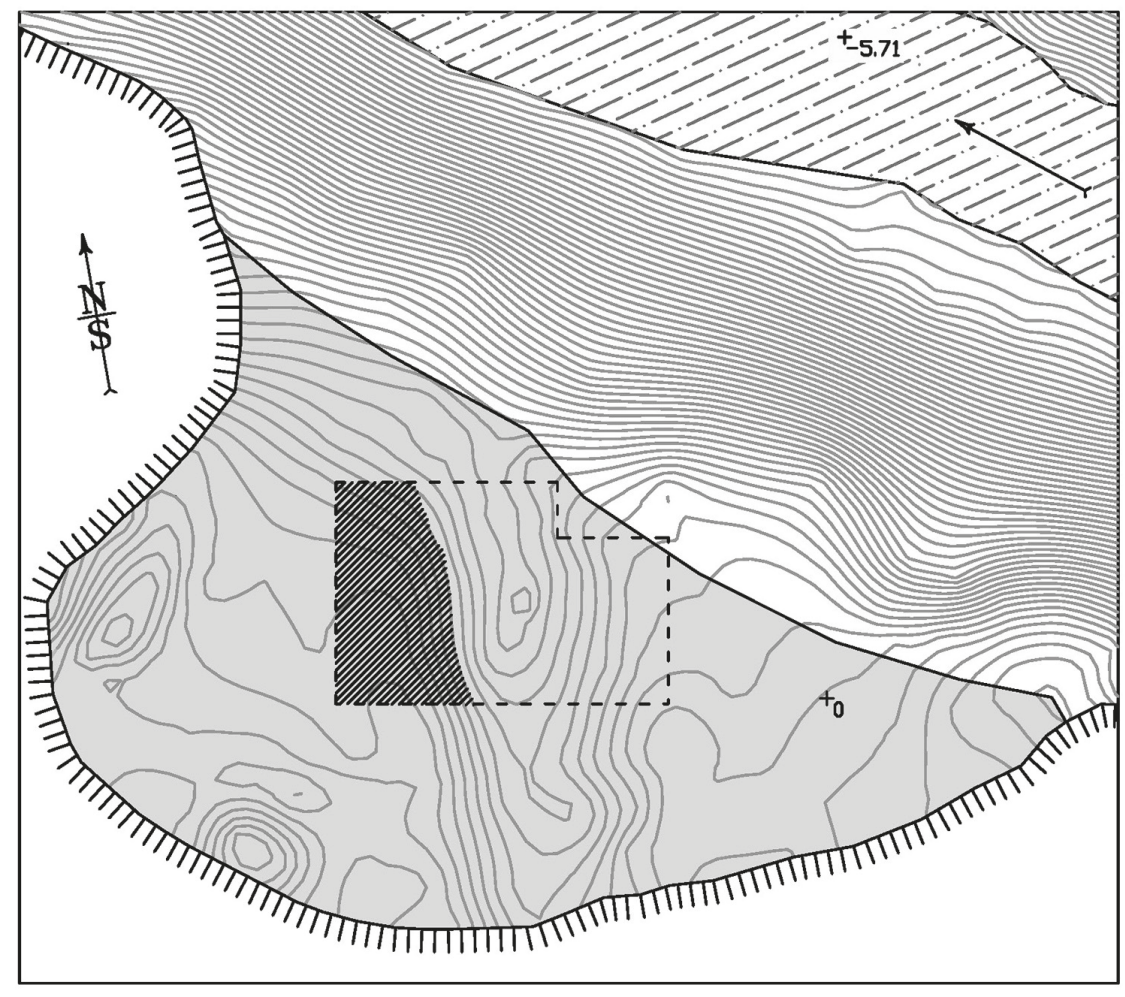

contour interval: $0,10 \mathrm{~m}$.
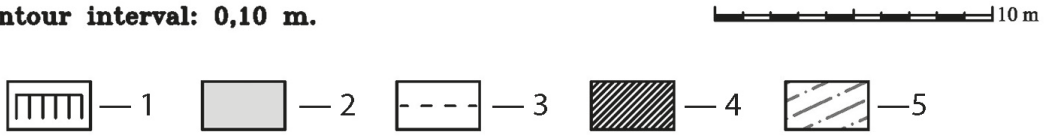

Fig. 1. Plan of the Meshoko rock shelter: 1 - rock; 2 - settlement area; 3 - excavation area (2011-2019); 4 - third layer area; 5 - the Meshoko Brook. Illustration by S. M. Ostashinskii, E. A. Cherlenok

\section{Stratigraphy}

Cultural deposits of the Meshoko rock shelter, despite their lesser thickness (about $1 \mathrm{~m}$ ), are divided into 6 main layers (Fig. 3). The first layer on the top contained a small amount of material, among which there were modern garbage as well as fragments of Maykop and Eneolithic pottery. Probably, it was formed as a result of a relatively recent human activity. The second layer was preserved only within a small area; its cultural attribution is still problematic. The third layer belonged to the Maykop culture. The fourth layer contained a minimal amount of material, possibly penetrating here from an overlying context. The fifth layer is associated only with finds of the local Eneolithic culture. The sixth layer has been actively studied for only two years, therefore, at present, only a rough evaluation can be given. The materials are characterized by the predominance of flint finds over ceramic fragments, the spread of thin walled pottery and various geometric microliths, especially segments. 


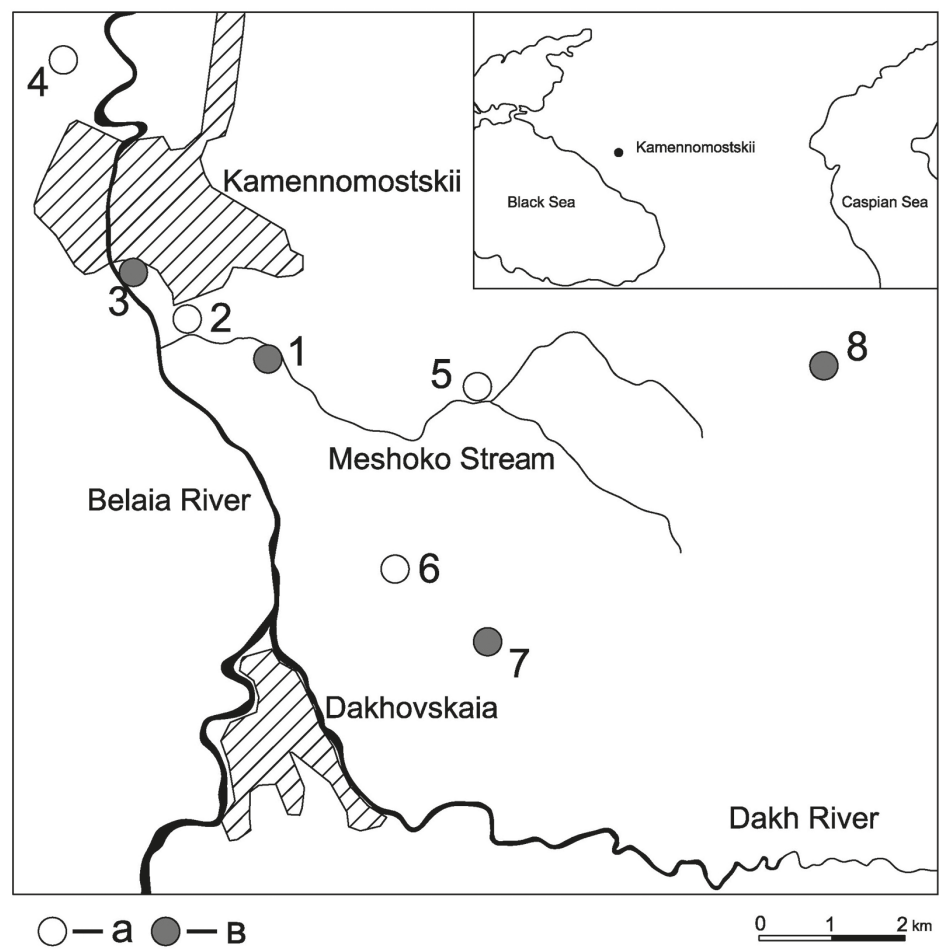

Fig. 2. The Eneolithic (a) and Eneolithic-Maykop (b) sites in the vicinity of the village of Kamennomostsky: 1 - Meshoko rock shelter; 2 - Meshoko settlement; 3 - Khadzhokh rock shelters; 4 - Skala settlement; 5 - Kamennomostskaya cave; 6 - Dakhovskaya cave; 7 Unakozovskaya cave; 8 - Khutor Veselyi settlement. Illustration by S. M. Ostashinskii, E. A. Cherlenok

The structure of the fourth layer plays an important role in the analysis of the problem of interaction between the Eneolithic and Maykop inhabitants. The average thickness is about $0.18-0.15 \mathrm{~m}$. The main distinguishing feature is a pronounced horizontal layering. In most sections, three black layers are clearly visible, between which there are deposits of white and gray, which, in turn, consist of many thin layers. In our opinion, the preservation of a fine undisturbed structure and a small number of finds indicates the absence of anthropogenic impact and the natural origin of the fourth layer ${ }^{12}$.

12 This conclusion is confirmed by another research: Samples from the upper and lower parts of the fourth layer were analyzed by Dr. Marianna A. Kulkova (Department of Geology and Geoecology, Herzen State Pedagogical University, St. Petersburg Russia). It turned out that the deposits are characterized by a low content of clay component, alumina $\left(\mathrm{Al}_{2} \mathrm{O}_{3}-3.89-4.96 \%\right)$ and a high content of sand component $\left(\mathrm{SiO}_{2}-\right.$ $66.18-58.91 \%)$ and carbonates $(\mathrm{CaO}-11.56-14.37 \%, \mathrm{MgO}-1.65-2.05 \%)$. The lower horizon of the fourth layer is characterized by a higher content of carbonates, and its black color can be explained by the increased content of a carbon or organogenic component in it. According to the researcher, these deposits could form in a stagnant shallow water environment and accumulate like layers. In wetter periods (summer) they are enriched with organic matter; in drier periods (winter) they do not contain it. 

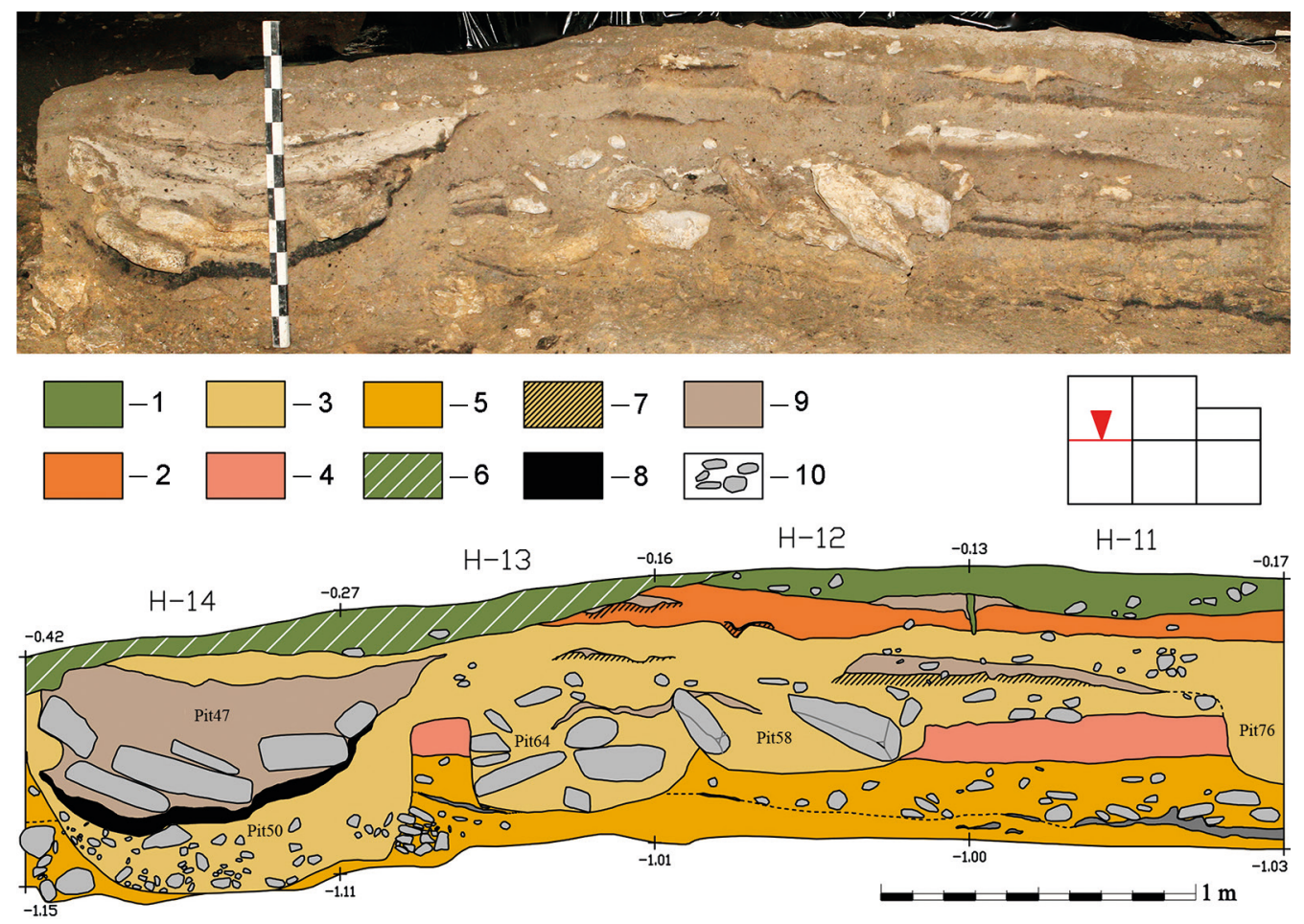

Fig. 3. Western part of the central section (the view from the north): 1 - first layer; $2-$ second layer; 3 - third layer (Maykop culture); 4 - fourth layer; 5 - fifth layer (Eneolithic culture); 6 mixed soil (the destruction of the trench of 1963); 7 - dark brown loam; 8 - charcoal; 9 - ash; $10-$ stones. Illustration by S. M. Ostashinskii, E. A. Cherlenok

\section{The objects}

The Maykop layer was preserved only in the western part of the excavation, on an area of about $28 \mathrm{~m}^{2}$. The thickness of the layer varies from 0.23 to $0.40 \mathrm{~m}$, averaging $0.30 \mathrm{~m}$. It consists of gray loam deposits, in which three levels of large ash spots were traced. The most common type of objects are several dozen pits of different sizes and depths. Some of them have unusual fills, the basis of which consisted of large limestones piled on top of each other without any order.

The most expressive structure discovered in the third layer is a hearth (Fig. 3, Pit 47). It was made in an earlier pit (№ 50) also dating back to the Maykop time. The hearth has a rounded shape; its length is $1.12 \mathrm{~m}$; width is $1.28 \mathrm{~m}$; depth is $0,45 \mathrm{~m}$. The walls of the recess gradually taper to the bottom. Along them lies a carbonaceous layer, on top of which there are flat limestones that form the base and inclined walls of the hearth. The entire space between the stones was filled with ash.

The hearths are also known in other Maykop settlements. A distinctive feature of their design is the use of clay, in particular for coating walls of the pits ${ }^{13}$. Obviously, the use of stones to create a hearth in the Meshoko rock shelter is associated with an abundance of

${ }^{13}$ Korenevskii S. N. Drevneishie zemledel'tsy i skotovody Predkavkaz'ia. P. 13. 
this material in the mountain zone. It should also be mentioned that in the Maykop culture, hearths are usually associated with dwellings. In the third layer traces of residential structures were not recorded. Perhaps the walls and ceiling of the rock shelter served as sufficient protection for the population.

\section{Synchronization of the third layer and the Eneolithic culture}

In total, about 3.5 thousand finds were discovered in the third layer. One of the main problems in the analysis of this assemblage is the theoretical possibility that artifacts from the underlying deposits could get into it. The most acute issue of attribution concerns rare items that do not have distinct Maykop analogies. Previously, all artifacts of this kind were divided into two groups, reflecting the degree of their presence in the underlying layers of the rock shelter.

The first group should include artifacts that do not have analogies in the underlying layers. First of all, they should include two bone needles with eyes (Fig. 4: 1-2) and a bone point (Fig. 4: 3). We attribute these artifacts to the Maykop culture, and their originality, apparently, should be interpreted as the result of the local features of the site.

The second group consists of finds that sometimes occur in the Maykop layer but are often found in the underlying layers. These include: a fragment of the pectoral from boar tusk ${ }^{14}$, a large flint bifacial point of triangular form ${ }^{15}$, a flint microlith of segment form ${ }^{16}$, eight fragments of ceramic "cones" ${ }^{17}$, a fragment of a ceramic vessel ornamented with drawn lines ${ }^{18}$, ten fragments of ceramic vessels ornamented with "pearls"19, and some other finds. All these artifacts, at the moment, cannot be confidently synchronized with the antiquities of the Maykop culture. It is more likely that they were introduced into the third layer through pits which were dug from a Maykop level.

\section{Synchronization of the third layer and the Maykop culture: individual finds}

A special group consists of single finds that can be confidently associated with artifacts from other Maykop sites. Their analysis is especially important since they and the study of mass material make it possible to synchronize the third layer of Meshoko rock shelter with one or another stage of the development of the Maykop culture.

${ }^{14}$ Cherlenok E.A., Ostashinskii S.M. Piatyi sloi navesa Meshoko: problema sinkhronizatsii s pamiatnikami stepnogo eneolita Vostochnoi Evropy // Arkheologiia Vostochno-Evropeiskoi stepi. No. 15. Saratov, 2019. P. 35.

15 Ibid. P. 34, Fig. 3:9.

16 Ostashinskii S. M., Cherlenok E. A. Kremnevye izdeliia navesa Meshoko (po materialam raskopok 2011-2012 gg.) // Problemy arkheologii epokhi kamnia: k 70-letiiy Valentiny Ivanovny Beliaevoi. St. Petersburg, 2014. P. 165, Fig. 1:2.

17 Ostašinskij S.M., Cerlenok E. A. Die Stratigrafie des Mešoko-Abris und das Problem der Wechselbeziehungen der Kulturen der Äneolithikum und der Bronzezeit im Nordwestkaukasus // Der Kaukasus zwischen Osteuropa und Vorderem Orient in der Bronze- und Eisenzeit: Dialog der Kulturen, Kultur des Dialoges: Internationale Fachtagung für die Archäologie des Kaukasus und Humboldt-Kolleg. Berlin, Dietrich-Reimer-Verlag, 2020. S. 47.

18 Ibid. S. 46.

19 Ibid. 


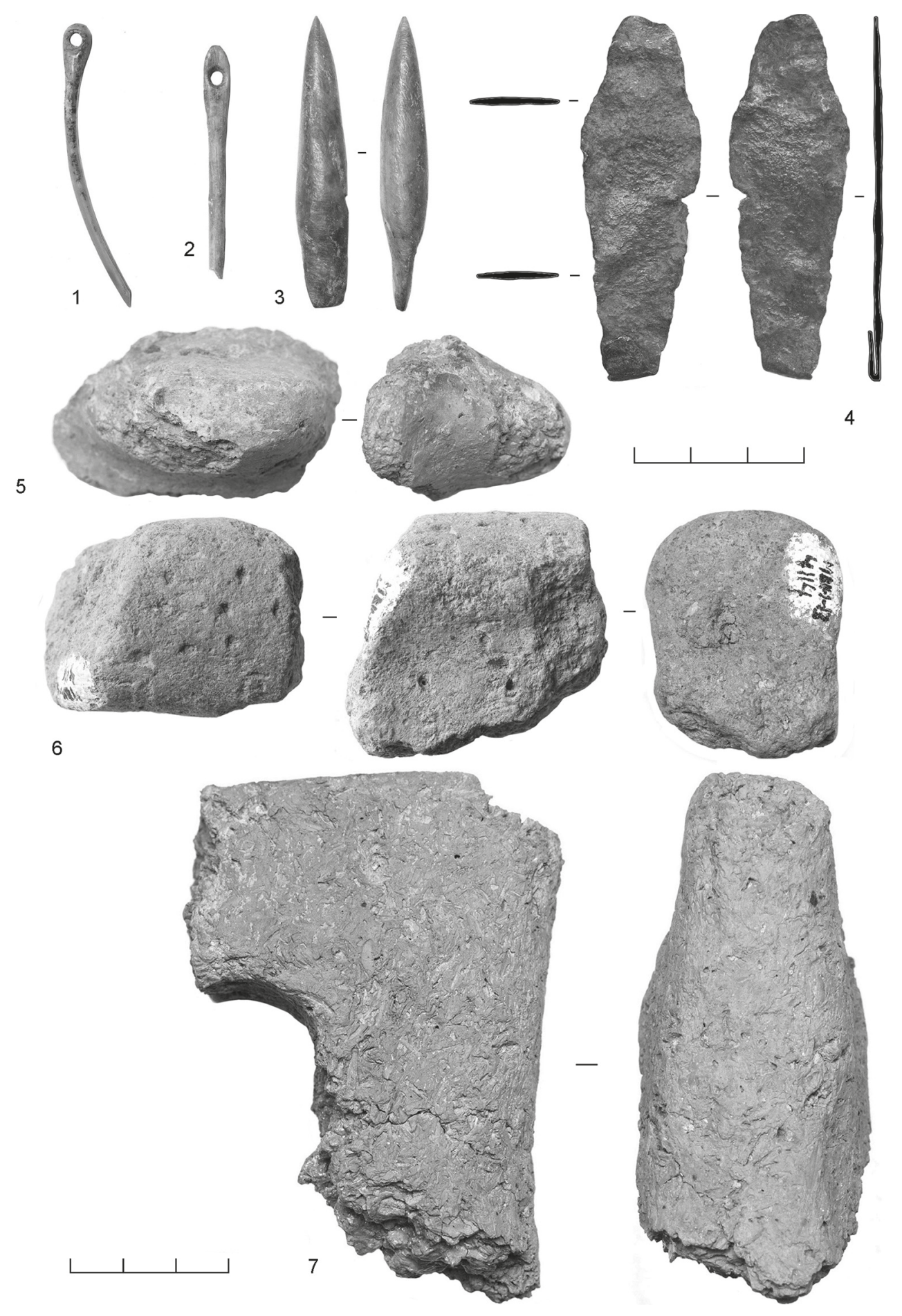

Fig. 4. Individual finds of the third layer (Maykop culture): $1-2-$ bone needles with eyes; $3-$ bone point; 4 - copper knife; 5 - horizontal handle; 6 - fragment of the hearth support (?); 7 fragment of the hearth support with a hole. Illustration by S. M. Ostashinskii, E. A. Cherlenok 
One of the most expressive artifacts of this kind is a copper ${ }^{20}$ knife. (Fig. 4: 4). It can be compared with a group of daggers with barely pronounced tangs. Probably this object can be attributed to the middle stage of metallurgy, according to the periodization of S. N. Korenevskii ${ }^{21}$ : on the one hand, daggers with barely pronounced tangs are not in the earliest complexes ${ }^{22}$, and on the other, at the late stage of Maykop metallurgy, they acquired a pronounced ribbing that is absent in our find ${ }^{23}$.

The Maykop culture is also characterized by the hearth supports ("cones"). Some ceramic fragments of the third layer probably can be referred to these artifacts as, for example, a fragment with a decoration at the top (Fig. 4: 6). But only in one case a large part of the hearth support with a hole was found (Fig. 4: 7). It is similar to the "cones" of group 4, according to S.N. Korenevskii, but it does not have pronounced protrusions ${ }^{24}$. The closest analogies come from the Maykop settlement of Pkhagugape ${ }^{25}$ and the sixth layer of the Razdorskoe 1 settlement ${ }^{26}$, belonging to the Konstantinovskaya Eneolithic culture.

The problem of the relative chronology of Maykop culture is still far from being solved. Nevertheless, it can be assumed that the Meshoko rock shelter dates from the middle stage of the Maykop culture. This, first of all, is indicated by the analogies of the hearth support. The settlement of Pkhagugape contained characteristic pottery with "polished" decoration, which allowed the author of the excavation to date it to the Inozemtsevo-Kostromskaya (or middle) stage ${ }^{27}$. At the same time, Konstantinovskaya's sites, one of which contained a second similar hearth support, are synchronized ${ }^{28}$.

\section{Synchronization of the third layer and the Maykop culture: pottery}

The most numerous category of finds (about $58 \%$ ) of the third layer is comprised by fragments of pottery. Previously, the ceramic assemblage was divided into two main groups. Shards with the visible mineral inclusions in the clay matrix are classified as the first. Vessels of the second group are made of clay without visible inclusions. In general, the distinguished groups correspond to the $1^{\text {st }}$ ("high") and $2^{\text {nd }}$ ("ordinary") pottery classes of the Maykop culture ${ }^{29}$.

20 The knife was analyzed by S. V. Khavrin (The State Hermitage Museum, Department of Scientific and Technical Examination of Monumetns). According to him this, artifact was made of pure copper with a natural admixture of arsenic (less than $1 \%$ ).

${ }^{21}$ Korenevskii S. N. Drevneishii metall Predkavkaz'ia. Tipologiia. Istoriko-kul'turnyi aspekt. Moskow, 2011. P. 41-44.

22 Ibid. P. 110.

23 Ibid. P. 58; Betrozov R. Zh., Nagoev A. Kh. Kurgany epokhi bronzy u selenii Chegem I, Chegem II i Kishpek (1-ia i 2-ia gruppy) // Arkheologicheskie issledovaniia na novostroikakh Kabardino-Balkarii v 1972-1979 gg. T. 1. Nalchik, 1984. Fig. 11: 15, 16.

${ }^{24}$ Korenevskii S. N. Drevneishie zemledel'tsy i skotovody Predkavkaz'ia. P. 40.

25 Not published. It is stored in the State Hermitage Museum, Department of Archaeology of Eastern Europe and Siberia.

${ }^{26}$ Kiiashko V. Ia. Mezhdu kamnem i bronzoi (Nizhnee Podon'e v V-III tysiacheletiiakh do n. e.). Azov, 1994. Fig. 7: 11.

27 Rezepkin A.D., Poplevko G. N. Poselenie Pkhagugape // Liber Archaeologicae. Krasnodar; Rostovon-Don, 2006. P. 116.

28 Trifonov V.A. Zapadnye predely rasprostraneniia Maykopskoi kul'tury // Izvestiia Samarskogo nauchnogo tsentra Rossiiskoi akademii nauk. Samara, 2014. Vol. 16, no. 3. P. 276-284.

${ }_{29}$ Korenevskii S. N. Galiugai 1 - poselenie Maykopskoi kul'tury (Arkheologicheskie istochniki po probleme drevneishikh zemledel'tsev i skotovodov na kavkazskoi granitse Perednei Azii i Vostochnoi Evropy). Moscow, 1995. P. 20-22. 
Shards of "high" class are the attributive artifacts of the third layer and make up about $13.5 \%$ of all detected fragments of pottery. In addition to the absence of visible inclusions, they are well baked and smoothed. The surface is predominantly black or gray; shards of orange and brown are less common. Pottery, apparently, has rounded base (Fig. 5: 5). The large vessels have outbent rims, which is often found on Maykop pottery (Fig. 5: 1; Fig. 6: $6-8$ ). The rim of the bowls mainly has a level ledge protruding from inner side (Fig. 5: 2-4; Fig. 6: 1-5) and belongs to the second type of the Maykop bowls, according to the classification of A. D. Rezepkin ${ }^{30}$.

The number of shards with mineral inclusions exceeds the number of fragments of the "high" class by about seven and a half times, which indicates a much more active use in everyday life. In shape, they resemble pottery without visible inclusions and are represented by bowls and jars with a bent rim. The only small horizontal handle in the ceramic assemblage of our excavations belongs to such elements of the form, which were possibly found only on "ordinary" pottery (Fig. 4: 5). A similar handle was discovered in the Galiugaevskoe settlement of the Maykop culture ${ }^{31}$.

Apart from distinct similarities between the ceramic assemblage of the Meshoko rock shelter and other sites of the Maykop culture, it is marked by a certain originality. This is evidenced by a small amount of the $1^{\text {st }}$ pottery class and the predominance of shards with black or gray surfaces over red fragments. The set of types is much poorer than in ordinary Maykop settlements. For example, shards of large open vessels ("chan"), which in the Ust'-Dzhegutinskoe settlement make up almost $30 \%^{32}$, have not yet been found in the rock shelter.

As in the case with individual finds, the analogies with the Maykop pottery from the Meshoko rock shelter testify in favor of the relatively early age of the site. This is confirmed by the complete absence of pottery with flat base as well as by the wide distribution of early bowls with rims of the second type. Interestingly, the largest number of such rims in the steppe were found in the settlement of Pkhagugape ${ }^{33}$, from which the closest analogy with the Meshoko hearth support comes.

\section{Paleoethnobotany}

In the course of work in the rock shelter, an expressive collection of botanical remains was collected. Although these materials have so far only been partially determined, it can be argued that they are based on the fruit of a wild pear - Pyrus L. ${ }^{34}$ The fruit of this plant, found both in the form of separate finds and in clusters, is a characteristic feature of the third cultural layer. Wild pears still grow on a plateau near the monument, which, on the one hand, indicates a certain similarity between ancient and modern flora, and on the

${ }^{30}$ Rezepkin A.D., Poplevko G.N. Klassifikatsiia misok poselenii Maykopskoi kul'tury // Zapiski Instituta istorii material'noi kul'tury RAN. St. Petersburg, 2009. No. 4. P. 81-89.

${ }_{31}$ Korenevskii S. N. Galiugai 1 - poselenie Maykopskoi kul'tury... P. 145, Fig. 60: 1.

${ }^{32}$ Rezepkin A.D. Poselenie Ust'-Dzhegutinskoe // Materialy po izucheniiu istoriko-kul'turnogo naslediia Severnogo Kavkaza. Iss. 11. Moscow, 2013. P. 42.

${ }^{33}$ Bochkovoi V.V., Marchenko I.I., Limberis N.Yu., Rezepkin A.D. Materialy poseleniia Chekon i klassifikatsiia keramiki Maykopskoi kul'tury // Kul'tury stepnoi Evrazii i ikh vzaimodeistvie s drevnimi tsivilizatsiiami: v 3 t. T.2. St. Petersburg, 2012. Fig. 1.

34 The materials were analyzed by I. G. Chukhina (N. I. Vavilov All-Russian Institute of Plant Genetic Resources (VIR)). 

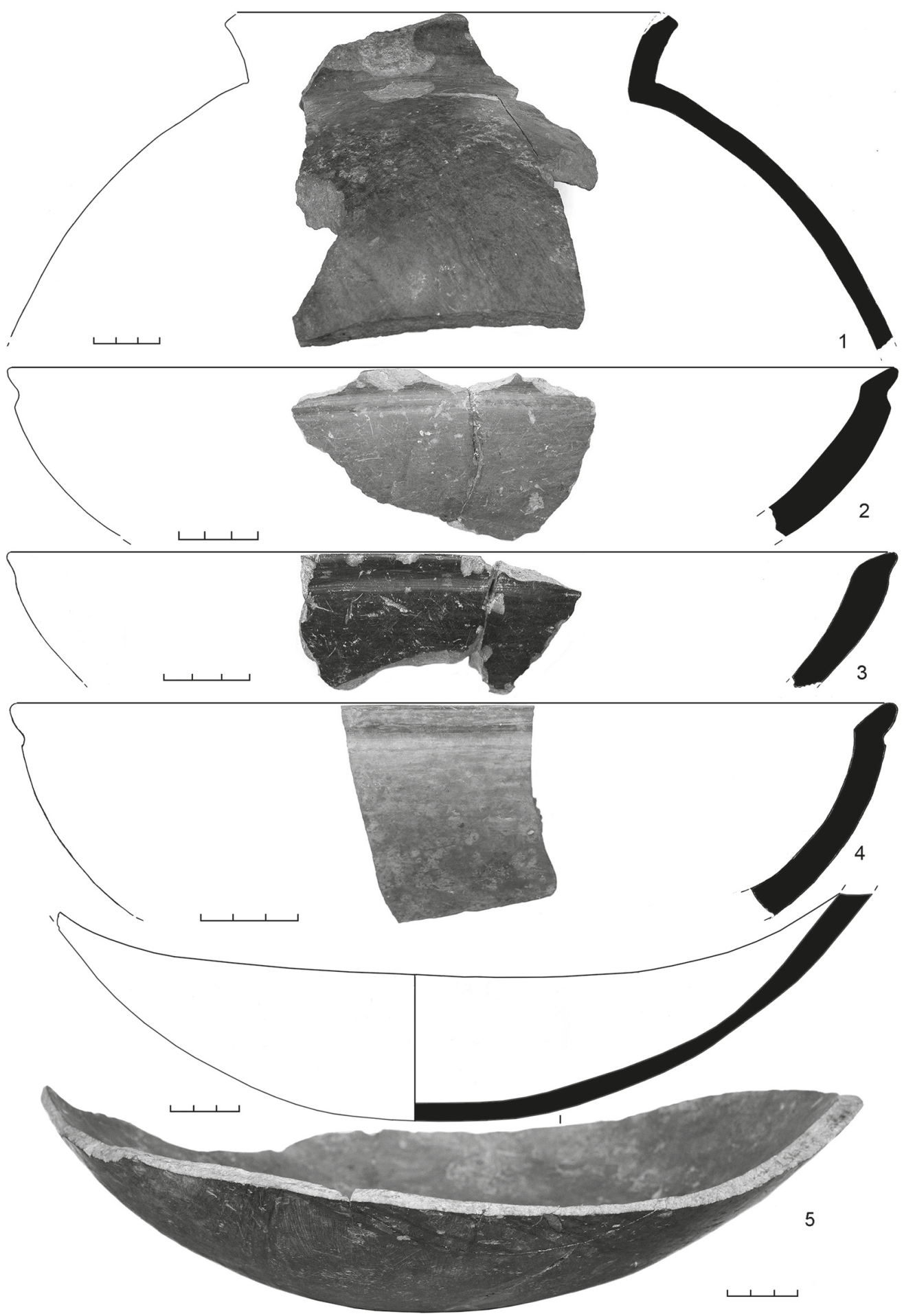

Fig. 5. Third layer. The big fragments of the "high" pottery class (Maykop culture): 1 - rim of the jar; 2-4 - rims of the bowls; 5 - base of the vessel. Illustration by S. M. Ostashinskii, E. A. Cherlenok 

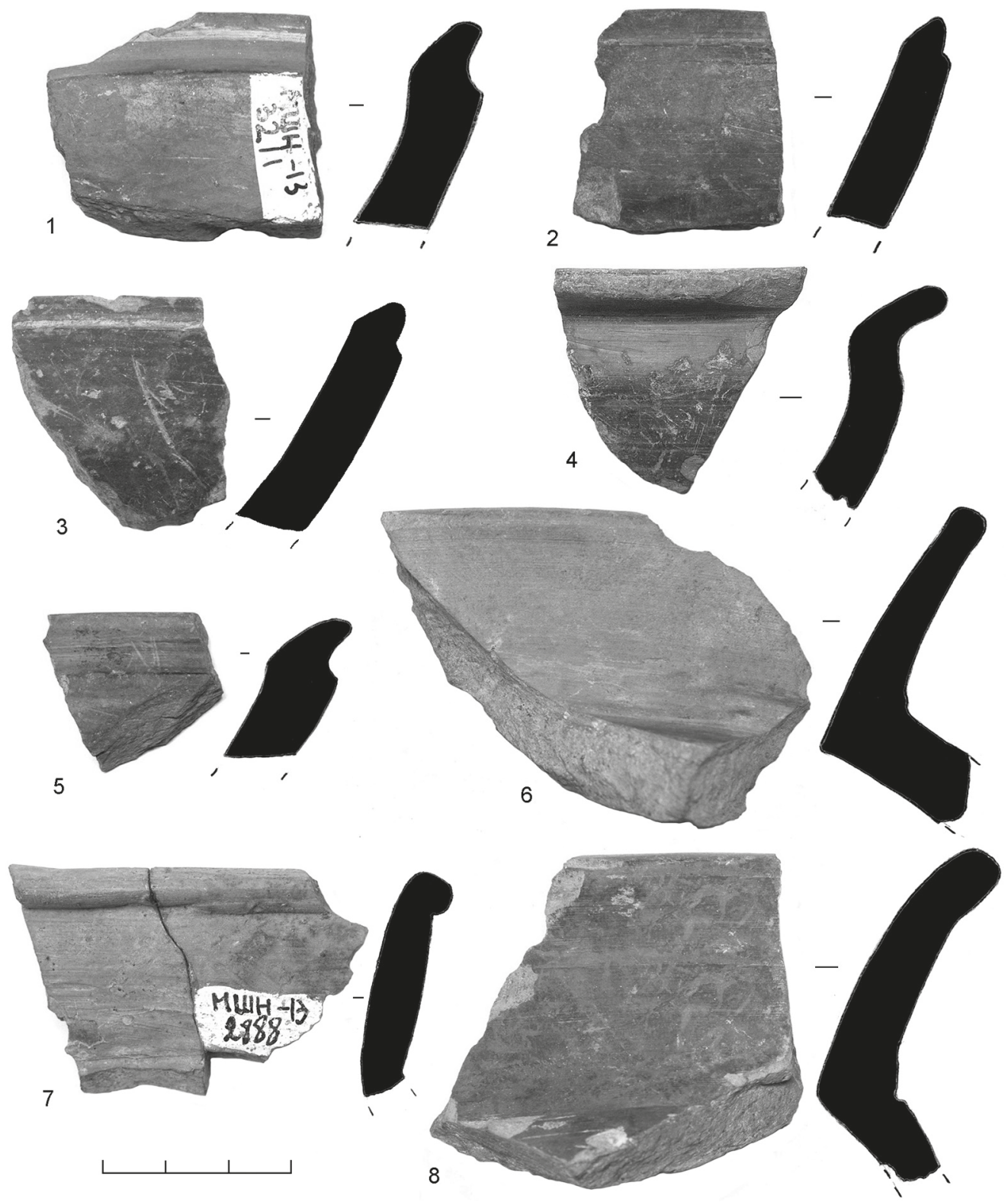

Fig. 6. Third layer. The small fragments of the "high" pottery class (Maykop culture): $1-5-$ rims of the bowls; 6-8 - rims of the jars. Illustration by S. M. Ostashinskii, E. A. Cherlenok

other, suggests that the rock shelter was inhabited in the autumn-summer period when the fruit of this plant ripens. Unfortunately, the botanical remains are almost unknown in the Maykop sites. Only the seeds of a local wild plant, which were discovered in one of the the pithoi of the Galiugaevskoe settlement, can be mentioned ${ }^{35}$. In comparison with the underlying Eneolithic deposits, the paleoethnobotanical assemblage of the third layer

${ }^{35}$ Korenevskii S. N. Galiugai 1 - poselenie Maykopskoi kul'tury... P. 78. 
shows a clear evidence of gathering. So, the fruit of the wild pear in the fifth layer has not been found, but grains of domestic cereals are abundantly represented ${ }^{36}$.

\section{Archaeozoology}

The animal bone fragments were found in a relatively small amount (about $22 \%$ of all finds). Pig bones predominate $(45 \%)^{37}$. Bones of sheep/goats make up $28 \%$, bovids $23 \%$, wild animals $-7 \%$. An important feature of the assemblage is the lack of horse bones. The composition of the assemblage is unusual for Maykop culture since the bones of sheep/goats or bovids prevailed in all other $\operatorname{sites}^{38}$. A considerable role of the pig in the economy of the inhabitants of the rock shelter is obviously explained by the convenience of keeping this species in the conditions of wooded mountains. In this regard, it is important to mention that a high percentage of pig bones is a characteristic feature of local sites of the previous time and, in particular, of the underlying Eneolithic layer of the Meshoko rock shelter ${ }^{39}$. Apparently, the absence of horse bones, which were discovered in some Maykop steppe settlements ${ }^{40}$, is also associated with local environment. The faunal remains of this animal are also absent from local Eneolithic sites ${ }^{41}$.

\section{Radiocarbon dates}

Based on the materials of the third layer of the Meshoko rock shelter, eight radiocarbon dates were determined (Fig. 7). The samples for them were wild pear fruit, charcoal, and animal bones. The dating was carried out in the Isotope Center of the Faculty of Geography in Herzen State Pedagogical University $(\mathrm{SPb})$, in the Budker Institute of Nuclear Physics of the Siberian Branch of the Russian Academy of Sciences (BINP_NSU), and in the laboratory of the Institute for the History of Material Culture of the Russian Academy of Sciences (Le). The calibrated values of these dates show significant variation. The most recent of them (Le 11478 and Spb1072) go beyond the existence of the Maykop culture. The earliest date (Le10475), on the contrary, is superimposed on the period of Eneolithic deposits $(3800-3600 \mathrm{BC})^{42}$. The remaining five dates can serve as the basis for establishing an absolute chronology. In our opinion, they enable to indicate the most probable time of existence of the Maykop layer only in a very wide range of about 3600-3000 BC.

36 Ostashinskii S.M., Cherlenok E.A., Loskutov I. G. Novye dannye o drevnem zemledelii SeveroZapadnogo Kavkaza // Arkheologicheskie vesti. 2016. No. 22. P. 35-40.

37 Hambleton E., Maltby M. The Animal Bones from Excavations in Meshoko Cave in the Northern Caucasus. 2016. P.22-23. URL: http://eprints.bournemouth.ac.uk/24860/1/MeshokoCaveReportJuly2016. pdf (accessed: 02.02.2020).

38 Korenevskii S. N. Drevneishie zemledel'tsy i skotovody Predkavkaz'ia. P. 74, Tab. XV; Spasovskii Iu. N. Resul'taty opredelenii osteologicheskikh sborov iz poselenii Maykopskoi kul'tury Novosvobodnenskoe i Pkhagugape (sezon 2006 g.) // Arkheologia Kavkaza i Blizhnego Vostoka. Moscow, 2008. Tab. 1.

39 Hambleton E., Maltby M. The Animal Bones from Excavations... P. 22-23.

40 Korenevskii S. N. Drevneishie zemledel'tsy i skotovody Predkavkaz'ia. P. 74. Tab. XV; Spasovskii Iu. N. Resul'taty opredelenii osteologicheskikh sborov... Tab. 1.

${ }^{41}$ Kasparov A.K., Sablin A. K. Faunisticheskie ostatki poseleniia Meshoko na Severnom Kavkaze // Meshoko - drevneishaia krepost' Predkavkaz'ia. Tabs. 1-3.

42 Ostašinskij S. M., Čerlenok E. A. Die Stratigrafie des Mešoko-Abris... P. 51, Fig. 9. 


\begin{tabular}{|c|c|c|c|c|}
\hline Lab. code & Material type & Context & BP & cal. BC $95.4 \%$ prob. \\
\hline Le-11478 & Animal bones & Layer 3; Sq. и11 & $4060 \pm 100$ & $2888-2346(95.4 \%)$ \\
\hline $\mathrm{SPb}-1072$ & $\begin{array}{l}\text { Fruit of a wild } \\
\text { pear (Pyrus L.) }\end{array}$ & Layer 3 & $4200 \pm 70$ & $2917-2579(95.4 \%)$ \\
\hline Le-11475 & Animal bones & Layer 3; Sq. M-H11 & $4510 \pm 100$ & $\begin{array}{c}3508-3426(6.8 \%) \\
3382-2915(88.6 \%)\end{array}$ \\
\hline Le-11477 & Animal bones & $\begin{array}{c}\text { Layer } 3 \text {; Sq. И12-13 } \\
\text { and K12-13 }\end{array}$ & $4530 \pm 100$ & $\begin{array}{l}3516-3397(11.5 \%) \\
3385-2925(83.9 \%)\end{array}$ \\
\hline Le-11476 & Animal bones & Layer 3; Sq. К-л11 & $4610 \pm 100$ & $\begin{array}{c}3635-3087(93.5 \%) \\
3060-3030(1.9 \%)\end{array}$ \\
\hline BINP_NSU_1208 & $\begin{array}{l}\text { Fruit of a wild } \\
\text { pear (Pyrus L.) }\end{array}$ & Layer 3; Pit 54a & $4685 \pm 55$ & $\begin{array}{l}3632-3561(19.1 \%) \\
3537-3364(76.3 \%)\end{array}$ \\
\hline BINP_NSU_1207 & Pig teeth & $\begin{array}{l}\text { Layer 3; Sq. M13, } \\
\text { point } 1048\end{array}$ & $4840 \pm 45$ & $\begin{array}{l}3708-3621(55.1 \%) \\
3607-3522(40.3 \%)\end{array}$ \\
\hline Le-10475 & Charcoal & Layer 3; Hearth & $4900 \pm 110$ & $\begin{array}{l}3956-3506(92 \%) \\
3427-3381(3.4 \%)\end{array}$ \\
\hline
\end{tabular}

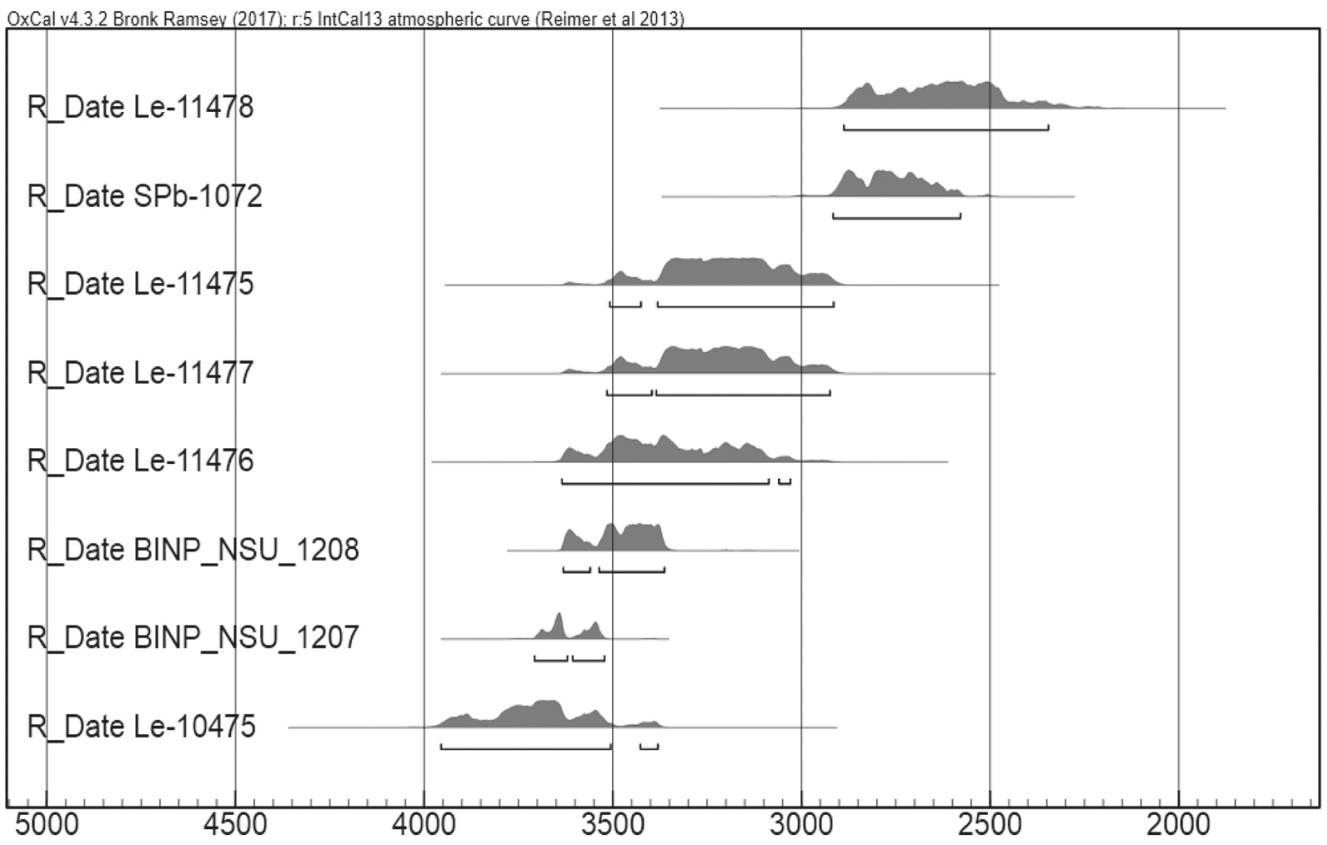

Fig. 7. Third layer. The radicarbon dates. Illustration by S. M. Ostashinskii, E. A. Cherlenok

\section{Discussion}

The most extensive evidence of the Maykop culture in the Northwest Caucasus is associated with the Belaya River basin. Similarly to the Meshoko rock shelter before the start of our work, they demonstrated the assemblage of Maykop and Eneolithic artifacts in the 
same context. But a repeated study of the Meshoko rock shelter showed that the people of the Eneolithic and early Bronze Age successively lived in one site, and most likely did not overlap in time. This makes us cautious about the conclusions drawn from the study of the old collections. We hope that their re-examination can provide convincing evidence of the occurrence of Maykop and Eneolithic artifacts in different layers. In our opinion, this is especially likely in relation to Khadzhokh rock shelters, where, it seems, Maykop artifacts prevail over the Eneolithic one ${ }^{43}$.

\section{Conclusion}

The foothills of the Northwest Caucasus to the south and east of the Meshoko rock shelter are one of the classic territories for the distribution of Maykop sites. They were located in flat areas and probably existed in the forest-steppe ${ }^{44}$. In this regard, the Meshoko rock shelter is an unusual site. The paleoethnobotanical data confirm the existence of forests, and the location of the rock shelter in the lower part of the gorge indicates a settlement strategy which was more typical of mountain peoples. One of the most unexpected results is that the Maykop population not only lived in a forest zone, but also used local resources for effective economic activity.

\section{References}

Betrozov R.Zh., Nagoev A. Kh. Kurgans of the Bronze Age near the Villages Chegem I, Chegem II and Kishpek ( $1^{\text {st }}$ and $2^{\text {nd }}$ Groups). Arkheologicheskie issledovaniia na novostroikakh Kabardino-Balkarii v 1972-1979 gg. Nal'chik, El’brus Publ., 1984, vol. 1, pp.7-87. (In Russian)

Bochkovoi V.V., Marchenko I.I., Limberis N. Yu., Rezepkin A.D. Materials of the Chekon Settlement and the Classification of Ceramics of the Maykop Culture. Kul'tury stepnoi Evrazii i ikh vzaimodeistvie s drevnimi tsivilizatsiiami. St. Petersburg, Periferiia Publ., 2012, vol.2, pp.95-100. (In Russian)

Cherlenok E. A., Ostashinskii S.M. The Fifth Layer of the Meshoko Rock Settlement: the Problem of Synchronization with the Eneolithic Steppe Monuments of the Eastern Europe. Arkheologiia Vostochno-Evropeiskoi stepi, no. 15. Saratov, Techno-Dekor Publ., 2019, pp. 31-43. (In Russian)

Formozov A. A. Archaeological Research of Caves in the Upper Reaches of the Belaya River in the Krasnodar Region. Sbornik materialov po arkheologii Adygei. No. 2. Maykop, Adygeiskoe knizhnoe izdatel'stvo Publ., 1961, pp.39-72. (In Russian)

Formozov A. A. Kamennomostskaya Cave - Multilayered Site in the Pre-Kuban Region. Paleolit i neolit SSSR, 1971, vol. 6, pp. 100-116. (In Russian)

Formozov A. A. Settlements of Adygea of the Early Metal Age. Sbornik materialov po arkheologii Adygei. No. 3. Maykop, Adygeiskoe knizhnoe izdatel'stvo Publ., 1972, pp.5-29. (In Russian)

Formozov A. A., Chernykh E. N. New Settlements of the Maykop Culture in the Pre-Kuban Region. Kratkie soobshcheniia Instituta arkheologii, 1964, iss. 101, pp. 102-110. (In Russian)

Kalinin P.I., Trifonov V.A., Shishlina N.I. Evolution of Chernozems of the Northwest Caucasus under the Influence of Climatic Changes in Late to the Holocene. Chernozemy Tsentralnoi Rossii: genezis, evoliutsiia i problemy ratsional'nogo ispol'zovaniia. Voronezh, Nauchhaia Kniga Publ., 2017, pp.77-81. (In Russian)

Kasparov A. K., Sablin A. K. Faunal Remains of the Meshoko Settlement in the North Caucasus. Meshoko drevneishaia krepost' Predkavkaz'ia. Otchety Severokavkazskoi arkheologicheskoi ekspeditsii 1958-

${ }^{43}$ Rezepkin A.D. Keramicheskie kompleksy poselenii Khadzhokh... P. 223-235.

${ }^{44}$ Kalinin P.I., Trifonov V.A., Shishlina N.I. Evoliutsiia chernozemov Severo-Zapadnogo Kavkaza pod vliianiem klimaticheskikh izmenenii v pozdnem golotsene // Chernozemy Tsentral'noi Rossii: genezis, evoliutsiia i problemy ratsional'nogo ispol'zovaniia. Voronezh, 2017. P. 77-81. 
1965 gg. St. Petersburg, Izdatel'stvo Gosudarstvennogo Ermitazha Publ., 2009, pp.215-223. (In Russian)

Kiiashko V. Ia. Between Stone and Bronze (Lower Don Region in V-III Millennia BC). Azov, Azovskii kraevedcheskii muzei Publ., 1994, 132 p. (In Russian)

Korenevskii S. N. Galugay I - the Settlment of Maykop Culture (The Archaeological Source on the Problem of Ancient Farmers and Cattle-Breeders on the Caucasus's Boundary of the Near East and the East Europe). Moscow, Institut arkheologii RAN Publ., 1995, 169 p. (In Russian)

Korenevskii S. N. The Ancient Farmers and Cattle Breeders of the Northern Caucasus. Moscow, Nauka Publ., 2004, 122 p. (In Russian)

Korenevskii S. N. The Ancient Metal of the Northern Caucasus. Typology. Historical and Cultural Aspect. Moscow, TAUS Publ., 2011, 336 p. (In Russian)

Korenevskii S. N. Eneolithic Settlement of the Northern Caucasus Yaseneva Polyana and the Culture of Ceramics with Pearls of the Northern Caucasus. Problemy istorii, filologii, kul'tury, 2008, no. 21, pp. 112148. (In Russian)

Lovpache N. G. Ethnic History of Western Circassia. Maykop, Adygeiskii gosudarstvennyi universitet Press, 1997, 168 p. (In Russian)

Ostashinskiy S. M. Materials of Excavation on Meshoko's settlement in 2007. Arkheologicheskie vesti, 2012, no. 18, pp. 43-66. (In Russian)

Ostashinskiy S. M. Materials of Excavation on Meshoko's settlement in 2008. Kavkazologia, 2019, no.3, pp. 38-61. (In Russian)

Ostashinskii S. M., Cherlenok E. A. Flint Artifacts from the Meshoko Rocksettlement (2011-2012 Excavations). Problemy arkheologii epokhi kamnia: k 70-letiiy Valentiny Ivanovny Beliaevoi. St. Petersburg, St. Petersburg State University Press, 2014, pp. 164-170. (In Russian)

Ostashinskii S.M., Cherlenok E.A. New Evidence on the Connections between the Late Eneolithic and Maykop Culture in the Foothills of the North-Western Caucasus. Shestaia Mezhdunarodnaia Kubanskaia arkheologicheskaia konferentsiia. Krasnodar, Ekoinvest Publ., 2013, pp. 321-324. (In Russian)

Ostashinskii S. M., Cherlenok E. A., Loskutov I. G. New Evidence on Ancient Agriculture in the North-Western Caucasus. Arkheologicheskie vesti, 2016, no. 22, pp. 35-40. (In Russian)

Ostašinskij S. M., Čerlenok E. A. Die Stratigrafie des Mešoko-Abris und das Problem der Wechselbeziehungen der Kulturen der Äneolithikum und der Bronzezeit im Nordwestkaukasus // Der Kaukasus zwischen Osteuropa und Vorderem Orient in der Bronze- und Eisenzeit: Dialog der Kulturen, Kultur des Dialoges: Internationale Fachtagung für die Archäologie des Kaukasus und Humboldt-Kolleg. Berlin, Dietrich-Reimer-Verlag, 2020, S. 41-53. (In German and Russian)

Rezepkin A.D. Ceramic Assemblages of Settlements Khadzhokh, Skala, Yasenova Polyana // Sud'ba uchenogo: K 100-letiiu so dnia rozhdeniia Borisa Aleksandrovicha Latynina. St. Petersburg, Izdatel'stvo Gosudarstvennogo Ermitazha Publ., 2000, pp. 223-235. (In Russian)

Rezepkin A.D. Ust'-Dzhegutinskoe Settlement. Materialy po izucheniiu istoriko-kul'turnogo naslediia Severnogo Kavkaza. Moscow, Pamiatniki istoricheskoi mysli Publ., 2013, iss. 11, pp. 39-70. (In Russian)

Rezepkin A. D., Poplevko G. N. Classification of Earthenware Basins from the Maykop Culture Sites. Zapiski Instituta istorii material'noi kul'tury RAN, 2009, no. 4, pp. 81-89. (In Russian)

Rezepkin A. D., Poplevko G. N. Pkhagugape Settlement. Liber Archaeologicae. Sbornik statei, posviashchennyi 60-letiiu Borisa Aronovicha Raeva. Krasnodar, Rostov-on-Don, Izdatel'stvo Iuzhnogo nauchnogo tsentra Rossiiskoi akademii nauk Publ., 2006, p. 116. (In Russian)

Rysin M. B. Problems of Chronology and Periodization of Ancient Cultures of the Caucasus (Radiocarbon "Revolution" and the Traditional Archaeological Typology). Arkheologicheskie vesti, 2012, no.18, pp. 204-231. (In Russian)

Spasovskii Iu. N. Results of the Analysis of Faunal Remains from the Settlements of the Maykop Culture Novosvobodnenskoe and Pkhagugape (2006 Excavations). Arkheologia Kavkaza i Blizhnego Vostoka. Moscow, TAUS Publ., 2008, pp. 256-258. (In Russian)

Stoliar A.D. Report on the Work of the North Caucasian Expedition of the State Hermitage in 1963. Meshoko - drevneishaia krepost' Predkavkaz'ia. Otchety Severokavkazskoi arkheologicheskoi ekspeditsii 1958-1965 gg. St. Petersburg, Izdatel'stvo Gosudarstvennogo Ermitazha Publ., 2009, pp.99-135. (In Russian) 
Trifonov V. A. Darkveti-Meshoko Culture. Tret'ia Kubanskaia archeologicheskaia konferentsiia. Krasnodar, Anapa, [n. s.], 2001, pp. 190-194. (In Russian)

Trifonov V.A. Local Chronological Peculiarities of Development of the Maykop Culture. Maykopskii fenomen $v$ drevnei istorii Kavkaza i Vostochnoi Evropy. Leningrad, Leningradskoe otdelenie Instituta archeologii Akademii nauk SSSR Publ., 1991, pp.25-29. (In Russian)

Trifonov V.A. Western Boundaries of Extension of the Maykop Culture. Izvestiia Samarskogo nauchnogo tsentra Rossiiskoi akademii nauk, 2014, vol.16, no.3, pp.276-284. (In Russian)

Статья поступила в редакцию 20 апреля 2020 г.

Рекомендована в печать 12 марта 2021 г.

Received: April 20, 2020

Accepted: March 12, 2021 